\title{
PENGARUH AUDIT TENURE, UKURAN PERUSAHAAN, DAN UKURAN KAP TERHADAP KUALITAS AUDIT PERUSAHAAN YANG TERDAFTAR DI INDEKS LQ45 BURSA EFEK INDONESIA \\ Oleh:
}

\author{
Annisa Sekar Irsa Fajrina
}

Politeknik Keuangan Negara STAN

Email : 1401190280_annisa@pknstan.ac.id

Julaika Putri Rohkhayatim

Politeknik Keuangan Negara STAN

Email : 1401190235_julaika@ pknstan.ac.id

\begin{tabular}{l}
\hline Article Info \\
\hline Article History : \\
Received 24 Juny - 2021 \\
Accepted 05 Sept - 2021 \\
Available Online 25 Sept- \\
2021
\end{tabular}

Keyword:

Audit Tenure, Firm Size,

Public Accounting Firm

Size, Audit Quality

\section{PENDAhuluan}

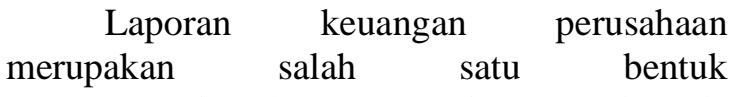
pertanggungjawaban manajemen kepada pemilik perusahaan yaitu pemegang saham. Selain itu, berbagai informasi akuntansi yang menggambarkan kinerja perusahaan selama suatu periode tertentu akan terlihat dalam laporan keuangan. Oleh karena itu, laporan keuangan menjadi suatu hal yang penting bagi pihak-pihak yang berkepentingan dengan perusahaan seperti pemegang saham dan kreditor dalam pengambilan keputusan. Namun, adanya kepentingan yang berbeda antara manajemen dan pemegang saham menyebabkan adanya konflik kepentingan. Jensen dan Meckling (1976) menyatakan hubungan agensi muncul ketika satu orang atau lebih (principal) mempekerjakan orang lain (agent) untuk memberikan suatu jasa dan kemudian mendelegasikan wewenang pengambilan keputusan kepada agen tersebut. Konflik kepentingan ini dapat menyebabkan informasi yang ada di dalam 
laporan keuangan menjadi tidak reliable. Auditor eksternal melalui Kantor Akuntan Publik (KAP) merupakan mediator dari kepentingan kedua pihak tersebut dan bertugas untuk mengevaluasi dan melakukan penilaian tentang tingkat kewajaran laporan keuangan yang dihasilkan manajemen berdasarkan standar yang berlaku (Febriyanti, 2014). Penilaian kewajaran laporan keuangan oleh auditor dilakukan dalam sebuah proses audit. Melalui audit, kepastian atas kualitas informasi yang ada di dalam sebuah laporan keuangan dapat diperoleh. Informasi keuangan yang lebih berkualitas dapat ditingkatkan dengan cara meningkatkan kualitas audit (Permana, 2011). Kualitas audit adalah audit yang sudah dilakukan dengan melaksanakan dan mematuhi standar profesi serta ketentuan hukum dan peraturan yang berlaku juga menerbitkan laporan auditor yang sesuai dengan kondisinya (Standar Audit IAPI 220, 2013). Menurut De Angelo (1981), kualitas audit merupakan adanya kecenderungan auditor akan mendeteksi dan mengungkapkan adanya fraud yang terdapat dalam laporan keuangan klien. Kualitas audit yang baik akan menghasilkan informasi yang sangat berguna di dalam melakukan pengambilan keputusan.

Pengguna laporan keuangan termasuk investor saham membutuhkan laporan keuangan untuk mengambil keputusan dan hasil audit berupa opini dari auditor membantu menunjukan kualitas informasi laporan keuangan yang dibacanya. Namun tidak semua hasil audit memiliki kualitas sesuai yang diharapkan oleh pengguna laporan keuangan seperti ketika terjadi kasus laporan keuangan PT. Kimia Farma Tbk. (KAEF) tahun buku 2001. Saat itu terjadi over-statement laba sebesar 99 miliar Rupiah dan KAP Hans Tuanakotta \& Mustofa (HTM) yang melakukan audit diduga terlibat dalam aksi penggelembungan tersebut.

Kualitas audit merupakan hal yang masih banyak dipelajari dan diperdebatkan, baik oleh akademisi maupun profesional yang berpraktik di bidang keuangan, hal ini dibuktikan dengan banyaknya penelitian terkait kualitas audit dalam sepuluh tahun terakhir. Berbagai proksi yang berbeda digunakan untuk mengukur kualitas audit, misalnya opini going concern, ukuran auditor, manajemen laba, dan persepsi auditor (Chadegani, 2011). Di dalam penelitian ini, terdapat 3 variabel yang diuji pengaruhnya dengan kualitas audit, di antaranya adalah audit tenure, ukuran perusahaan, dan ukuran KAP.

Audit tenure merupakan lamanya perikatan antara auditor dengan sebuah perusahaan sebagai klien dalam pemberian jasa audit atas laporan keuangan. Lama perikatan auditor dengan klien dianggap sebagai gambaran independensi auditor, khususnya terkait independence in appearance, dimana auditor harus menghindari situasi yang dapat membuat orang lain mengira bahwa dia tidak mempertahankan pola pikiran yang adil (Porter et al., 2003). Pramaswaradana (2017) mengungkapkan bahwa masa perikatan sempat menjadi perdebatan publik karena jika dilakukan terlalu lama maupun singkat akan berdampak buruk bagi auditor dan klien.

Beberapa penelitian terdahulu mengenai audit tenure dan kualitas audit telah dilakukan dan memberikan hasil akhir penelitian yang berbeda. Kurniasih (2014) menyatakan bahwa audit tenure berpenaruh negatif pada kualitas audit. Penelitian Panjaitan (2014) yang menyimpulkan audit tenure berpengaruh negatif pada kualitas audit. Penelitian Pramaswaradana (2017) juga menghasilkan simpulan bahwa audit tenure berpengaruh negatif pada kualitas audit. Di sisi lain, Sinaga (2012) menyatakan bahwa audit tenure tidak berpengaruh pada kualitas audit, begitupun penelitian Maharani (2014) tentang kualitas audit yang menghasilkan simpulan bahwa audit tenure tidak berpengaruh pada kualitas audit.

Ukuran perusahaan merujuk pada besarnya aset total yang dimiliki dan nilai total kapitalisasi saham suatu perusahaan. Variabel ukuran perusahaan dipilih menjadi salah satu variabel di dalam penelitian ini karena ukuran perusahaan merupakan salah satu karakteristik perusahaan yang menunjukan kinerja perusahaan dan sistem pengendalian intern perusahaan, dimana kedua poin tersebut akan berpengaruh dalam proses audit secara umum. Perusahaan besar dianggap memiliki manajemen yang berpengalaman dengan sistem pengendalian intern yang baik sehingga perusahaan besar akan menghasilkan audit yang lebih berkualitas dibandingkan perusahaan kecil (Fernado et al., 2010).

Penelitian terdahulu terkait variabel ini dilakukan oleh Febriyanti, et al (2014) yang menyatakan bahwa variabel ukuran perusahaan klien memiliki pengaruh positif dan signifikan terhadap kualitas audit, hal ini sejalan dengan penelitian Mgbame, et al. (2012) yang 
menyimpulkan bahwa ukuran perusahaan memiliki pengaruh positif terhadap kualitas audit perusahaan. Sementara itu, penelitian Paramita \& Latrini (2015) justru menyimpulkan bahwa ukuran perusahaan tidak berpengaruh pada kualitas audit.

Selain itu, ukuran KAP juga diasosiasikan dengan kualitas audit. Ukuran KAP dikaitkan dengan kompetensi auditor dalam melakukan audit. Dari sisi teori agensi, untuk mengurangi agency cost yang mungkin terjadi, perusahaan cenderung memilih jasa auditor besar yang profesional, independen, dan bereputasi baik untuk menghasilkan kualitas audit yang lebih baik (Watts dan Zimmerman, 1986). Namun, beberapa kasus audit yang terjadi di dunia justru terjadi ketika auditor berasal dari KAP berukuran besar, seperti di kasus Enron yang melibatkan KAP Arthur Andersen. Di Indonesia, KAP besar merujuk pada KAP yang berafiliasi dengan KAP The Big 4.

Penelitian terdahulu terkait ukuran KAP dan pengaruhnya terhadap kualitas audit menghasilkan hasil akhir yang berbeda-beda. Hasil penelitian yang dilakukan oleh Hartadi (2012) menyatakan bahwa rotasi dan reputasi kantor akuntan publik (KAP) tidak berpengaruh signifikan terhadap kualitas audit. Sedangkan penelitian Sinaga (2012) menyimpulkan bahwa ukuran KAP berpengaruh positif pada kualitas audit. Lalu Febriyanti et. al (2014) menyatakan bahwa ukuran KAP tidak berpengaruh signifikan terhadap kualitas audit. Kemudian, penelitian Cameran (2018) menghasilkan ukuran KAP yang dibagi menjadi 3 level organisasi KAP berpengaruh positif terhadap kualitas audit.

Perbedaan hasil penelitian terdahulu dan alasan pemilihan variabel dependen yang telah disebutkan sebelumnya terkait audit tenure, ukuran perusahaan dan ukuran KAP tersebut merupakan research gap yang menunjukkan bahwa masih diperlukan penelitian tambahan untuk menguji pengaruh ketiga variabel tersebut pada kualitas audit.

\section{KAJIAN PUSTAKA DAN PENGEMBANGAN HIPOTESIS Teori Agensi}

Teori Agensi dikembangkan oleh Jensen dan Meckling (1976) dan menjadi salah satu rujukan utama penelitian-penelitian berikutnya hingga saat ini. Jensen dan Meckling (1976) menyatakan bahwa organisasi merupakan jaringan kontraktual antara prinsipal dan agen yang melibatkan pendelegasian sebagian kewenangan pengambilan keputusan kepada agen. Teori agensi berkaitan dengan utility maximizers dimana ada kesempatan yang lebih besar untuk setiap pihak dalam memaksimalkan kepentingan sendiri

Arifin (2005) berpendapat bahwa adanya posisi, fungsi kepentingan, dan latar belakang prinsipal dan agen yang berbeda dan saling bertolak belakang namun saling membutuhkan ini, mau tidak mau dalam praktiknya akan menimbulkan pertentangan dengan saling tarik menarik kepentingan dan pengaruh antara satu sama lain. Teori keagenan berusaha menjawab masalah keagenan yang terjadi disebabkan karena pihak-pihak yang saling bekerja sama memiliki tujuan yang berbeda.

Perbedaan kepentingan dapat muncul di dalam perusahaan antara pemegang saham sebagai pemilik perusahaan dan manajer. Wibowo dan Rossieta (2009) menyatakan pihak ketiga yang independen merupakan pihak yang dapat menjadi mediator antara pemilik dengan agen dalam menyelesaikan permasalahan benturan kepentingan yang terjadi diantara keduanya. Auditor yang melakukan audit keuangan berperan sebagai mediator antara pemegang saham dan manajemen. Namun, masalah keagenan juga dapat muncul ketika proses audit dilaksanakan diantara auditor dan perusahaan sebagai kliennya.

Masalah keagenan tersebut dapat menimbulkan ketergantungan auditor pada kliennya. Ketergantungan auditor menyebabkan timbulnya pertentangan dengan prinsip auditor selaku pihak ketiga yang dituntut untuk independen dalam menjalankan audit dan dalam memberikan pendapat atas laporan keuangan klien. Hal ini disebabkan karena ketergantungan auditor melakukan akomodasi keinginan-keinginan manajemen dengan harapan perikatannya dengan klien tidak terputus, maka dapat menimbulkan mulai kehilangan independensinya dari seorang auditor (Kurniasih, 2014).

Oleh karena itu, ketika masalah keagenan muncul dalam proses audit dan independensi auditor mulai terganggu, standarstandar audit yang harusnya dipenuhi oleh auditor mungkin akan sulit dipenuhi dan berdampak pada kualitas audit yang dihasilkan.

\section{Kualitas Audit}


Dalam Standar Audit 220 (Institut Akuntan Publik Indonesia, 2013), kualitas audit didefinisikan sebagai audit yang sudah dilakukan dengan melaksanakan dan mematuhi standar profesi serta ketentuan hukum dan peraturan yang berlaku juga menerbitkan laporan auditor yang sesuai dengan kondisinya.

Menurut De Angelo (1981), kualitas audit merupakan adanya kecenderungan auditor akan mendeteksi dan mengungkapkan adanya fraud yang terdapat dalam laporan keuangan klien.

Kualitas audit terdiri atas kualitas sebenarnya (actual) dan dirasakan (perceived). Actual Quality adalah tingkat dimana resiko dari pelaporan salah saji material dalam rekening keuangan berkurang, sementara Perceived Quality adalah seberapa efektif pengguna laporan keuangan percaya bahwa auditor telah mengurangi salah saji material. Perceived audit quality yang lebih tinggi dapat membantu mempromosikan investasi pada klien yang diaudit (Jackson et al., 2008). Sejalan dengan itu, Permana (2011) menyatakan bahwa informasi keuangan yang lebih berkualitas dapat ditingkatkan dengan cara meningkatkan kualitas audit.

Meningkatkan kualitas dari pelaporan keuangan menambah nilai bagi laporan-laporan yang diajadikan alat bagi investor untuk memperkirakan nilai dari perdagangan saham. Peningkatan kualitas adalah sebuah fungsi tidak hanya deteksi auditor atas salah saji material, tetapi juga perilaku auditor terhadap deteksi ini. Maka dari itu, jika auditor memperbaiki salah saji material yang ditemukan, kualitas audit yang lebih tinggi dihasilkan, sementara itu kegagalan untuk memperbaiki salah saji material dan belum mampu mengeluarkan laporan audit yang bersih, menghalangi peningkatan kualitas audit (Johnson et al., 2002).

Kualitas audit secara umum menggambarkan kualitas laporan keuangan yang sesungguhnya. Sehingga dapat disimpulkan bahwa audit yang berkualitas dapat memenuhi dua aspek kualitas yaitu kualitas yang sebenarnya dan kualitas yang dirasakan, dimana kualitas yang sebenarnya terkait pengurangan salah saji material dan kualitas yang dirasakan terkait rasa percaya pengguna laporan keuangan bahwa laporan audit telah mengungkapkan salah saji material. Hal tersebut akan sangat bermanfaat bagi pengguna laporan keuangan dalam pengambilan keputusan.

Audit Tenure

Audit Tenure adalah Masa Perikatan (keterlibatan) antara Kantor Akuntan Publik (KAP) dan klien terkait jasa audit yang disepakati atau dapat juga diartikan sebagai jangka waktu hubungan auditor dan klien (Sinaga, 2012). Lama perikatan auditor dengan klien dianggap sebagai gambaran independensi auditor, khususnya terkait independence in appearance, dimana auditor harus menghindari situasi yang dapat membuat orang lain mengira bahwa dia tidak mempertahankan pola pikiran yang adil (Porter et al., 2003).

\section{Ukuran Perusahaan}

Besar perusahaan dapat dinyatakan dalam total aktiva, penjualan, dan kapitalisasi pasar. Semakin besar total aktiva, penjualan, dan kapitalisasi pasar maka semakin besar pula ukuran perusahaan itu (Sudarmadji dan Sularto, 2007).

Perusahaan kecil cenderung memiliki informasi dan sistem pengawasan yang lemah, sehingga kurang diperhatikan oleh pemegang sahamnya, sehingga perusahaan-perusahaan kecil akan menghasilkan audit yang lebih berkualitas (O'Brien dan Bhushan, 1990 dalam Fernando et al., 2010). Semakin besar perusahaan, semakin meningkat pula agency cost yang terjadi. Sehingga perusahaan berukuran besar akan cenderung memilih jasa auditor besar yang profesional, independen, dan bereputasi baik untuk menghasilkan kualitas audit yang lebih baik (Watts dan Zimmerman, 1986).

Novianti, dkk. (2010) menyatakan perusahaan besar akan memiliki kemampuan lebih untuk mengarahkan hasil audit. Hasil audit yang diarahkan ini menunjukkan bahwa kualitas audit yang dihasilkan mungkin tidak sesuai dengan yang diharapkan oleh pengguna laporan keuangan.

\section{Ukuran KAP}

Kantor Akuntan Publik yang selanjutnya disingkat KAP adalah badan usaha yang didirikan berdasarkan ketentuan peraturan perundang-undangan dan mendapatkan izin usaha berdasarkan Undang-Undang Nomor 5 Tahun 2011 tentang Akuntan Publik.

Perusahaan cenderung memilih jasa auditor besar yang profesional, independen, dan 
bereputasi baik untuk menghasilkan kualitas audit yang lebih baik (Watts dan Zimmerman, 1986 dalam Sinaga, 2012). Ukuran KAP dikaitkan dengan kompetensi auditor di KAP tersebut dalam melakukan audit (Sinaga, 2012). Cameran et. al (2018) mengklasifikasikan ukuran KAP menjadi 2 kategori yaitu KAP Big 4 dan KAP Non Big 4. Secara umum, KAP besar merujuk pada KAP yang berafiliasi dengan KAP Big 4.

KAP besar dipandang memiliki kemampuan untuk lebih mudah memenuhi standar-standar audit yang ditetapkan. Hal itu disebabkan oleh sumber daya auditor yang ada di KAP tersebut. Sehingga, audit yang dilakukan oleh KAP besar dianggap akan lebih berkualitas dan dapat menggambarkan kualitas laporan keuangan yang sesungguhnya

\section{Rumusan Hipotesis}

Hipotesis dalam penelitian ini adalah:

H1: Audit tenure memiliki pengaruh signifikan negatif pada kualitas audit

$\mathrm{H} 2$ : Ukuran perusahaan memiliki pengaruh signifikan positif pada kualitas audit

H3: Ukuran Kantor Akuntan Publik (KAP) memiliki pengaruh signifikan positif pada kualitas audit

Kerangka penelitian yang yang digunakan dapat digambarkan seperti pada Gambar 1 berikut

\section{Gambar 1. Kerangka Penelitian}

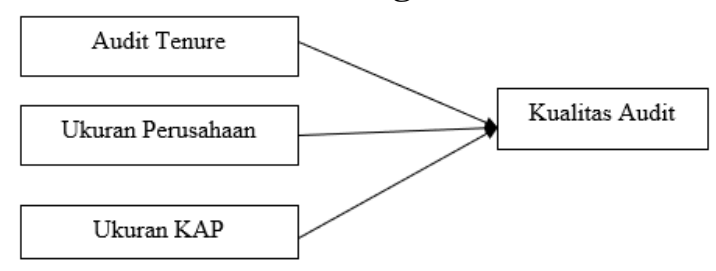

Sumber: Diolah oleh Penulis

\section{METODE PENELITIAN}

Penelitian dilakukan dengan pendekatan kuantitatif menggunakan analisis regresi data panel dengan Fixed Effect Model (FEM). Regresi data panel digunakan untuk mendapatkan hasil yang robust dengan data penelitian yang bersifat kombinasi dari crosssectional dan time series. Objek dari penelitian ini adalah perusahaan yang terdaftar di Indeks LQ45 Bursa Efek Indonesia.
Data yang digunakan dalam penelitian ini merupakan data sekunder yang diperoleh dari halaman website Bursa Efek Indonesia, meliputi Laporan Keuangan masing-masing perusahaan periode tahun 2016-2018.

Populasi dari penelitian ini adalah perusahaan yang terdaftar pada indeks LQ45 di Bursa Efek Indonesia dan sampel yang digunakan adalah perusahaan yang memenuhi kriteria sampling.

Sampling dilakukan secara purposive sampling dimana perusahaan yang menjadi merupakan perusahaan yang konsisten berada di Indeks LQ45 Bursa Efek Indonesia pada periode Agustus 2018 hingga Januari 2019 serta memiliki data lengkap terkait variabel penelitian. Dalam hal terdapat perusahaan yang tidak atau belum terdaftar pada semester kedua 2018 namun terdaftar pada periode sebelumnya, maka tidak akan dimasukkan ke dalam daftar perusahaan yang menjadi objek penelitian.

Analisis yang dilakukan dalam penelitian ini adalah analisis regresi dengan data berupa data panel. Tahapan pengujian dimulai dengan statistik deskriptif untuk menjelaskan data yang telah diperoleh dan dikumpulkan tanpa membuat kesimpulan akhir dari data tersebut. Kemudian dilakukan pemilihan model regresi yang paling sesuai. Uji Hipotesis juga dilakukan meliputi Uji Koefisien Determinasi (R-Squared), Uji Parsial (Uji t), dan Uji Simultan (F).

\section{HASIL DAN PEMBAHASAN}

Terdapat 33 perusahan yang memenuhi kriteria sampling dan dilakukan 99 observasi total yang meliputi data tahun 2016-2018.

Tabel 1. Hasil Pemilihan Sampel

\begin{tabular}{|c|c|c|}
\hline & Kriteria Pemilihan Sampel & $\mathbf{N}$ \\
\hline 1 & $\begin{array}{l}\text { Perusahaan yang konsisten } \\
\text { terdaftar di indeks LQ45 BEI } \\
\text { periode Agustus } 2018 \text { - Januari } \\
2019\end{array}$ & $\begin{array}{c}44 \\
\text { Perusahaan }\end{array}$ \\
\hline 2 & $\begin{array}{l}\text { Dikurangi perusahaan yang tidak } \\
\text { memiliki data terkait variabel } \\
\text { penelitian }\end{array}$ & $\begin{array}{c}11 \\
\text { Perusahaan }\end{array}$ \\
\hline \multirow[t]{3}{*}{3} & Total sampel penelitian & $\begin{array}{c}33 \\
\text { Perusahaan }\end{array}$ \\
\hline & Jumlah tahun (t): 2016-2018 & 3 tahun \\
\hline & Total sampel observasi & $\begin{array}{c}99 \\
\text { Observasi }\end{array}$ \\
\hline
\end{tabular}


Analisis statistik deskriptif yang dilakukan berdasarkan data yang dihimpun adalah sebagai berikut

Tabel 2. Analisis Statistik Deskriptif

\begin{tabular}{|l|c|c|c|c|}
\hline & Min & Max & Mean & $\begin{array}{c}\text { Std. } \\
\text { Deviatio } \\
\mathrm{n}\end{array}$ \\
\hline $\begin{array}{l}\text { Audit } \\
\text { Tenure }\end{array}$ & 1,0000 & 4,0000 & 2,7272 & 0,977483 \\
\hline $\begin{array}{l}\text { Ukuran } \\
\text { Perusa- } \\
\text { haan }\end{array}$ & 4,6077 & 1202,252 & 137,121 & 246,9970 \\
\hline $\begin{array}{l}\text { Ukuran } \\
\text { KAP }\end{array}$ & 0,0000 & 1,0000 & 0,79798 & 0,403351 \\
\hline $\begin{array}{l}\text { Kualitas } \\
\text { Audit }\end{array}$ & $-288,22$ & $-1,5731$ & $-10,602$ & 32,6655 \\
\hline
\end{tabular}

Sumber: Data diolah dengan EViews

Selanjutnya dilakukan pemilihan model regresi data panel melalui Uji Chow dan Uji Hausman dan model yang terpilih adalah Fixed Effect Model (FEM) dengan persamaan:

$$
\mathbf{A Q}=\alpha+\beta_{1} \text { TNRit }+\boldsymbol{\beta}_{2} U K R i t+\beta_{3} K A P_{i t}+
$$

$\varepsilon$.
Hasil analisis regresi yang terjadi tergambar pada Tabel 3 berikut

Tabel 3. Hasil Regresi Fixed Effect Model

\begin{tabular}{|c|c|c|c|c|}
\hline \multicolumn{5}{|c|}{$\begin{array}{l}\text { Dependent Variable: AQ } \\
\text { Total panel (balanced) observations: } 99\end{array}$} \\
\hline Variable & Coefficient & Std. Error & t-Statistic & Prob. \\
\hline $\mathrm{C}$ & 2.086809 & 10.57593 & 0.197317 & 0.8440 \\
\hline TNR & -10.02779 & 3.280867 & -3.056446 & 0.0029 \\
\hline UKR & 0.003140 & 0.013013 & 0.241282 & 0.8099 \\
\hline KAP & 17.83137 & 8.063369 & 2.211404 & 0.0294 \\
\hline R-squared & 0.119602 & \multicolumn{2}{|l|}{ Mean dependent var } & -10.60210 \\
\hline Adjusted R-squared & 0.091800 & \multicolumn{2}{|l|}{ S.D. dependent var } & 32.66554 \\
\hline S.E. of regression & 31.13011 & \multicolumn{2}{|l|}{ Akaike info criterion } & 9.753793 \\
\hline Sum squared resid & 92062.94 & \multicolumn{2}{|l|}{ Schwarz criterion } & 9.858646 \\
\hline Log likelihood & -478.8128 & \multicolumn{2}{|l|}{ Hannan-Quinn criter. } & 9.796217 \\
\hline F-statistic & 4.301906 & \multicolumn{2}{|l|}{ Durbin-Watson stat } & 1.670682 \\
\hline Prob(F-statistic) & 0.006842 & & & \\
\hline
\end{tabular}

Sumber: Data diolah dengan Eviews

\section{Hasil regresi yang terbentuk adalah: \\ $A Q=2.086809-10.02779 \mathrm{TNR}+0.003140 \mathrm{UKR}+17.83137 \mathrm{KAP}+\mathrm{e}$}

Hasil regresi tersebut menjelaskan bahwa:

1) Nilai konstanta 2.086809 yang artinya seluruh variabel independen nilainya 0 , maka kualitas audit akan bernilai sebesar 35,126

2) Variabel Audit Tenure bernilai -10.02779, yang artinya ketika audit tenure meningkat satu satuan maka akan mengurangi kualitas audit sebesar 10.02779

3) Variabel Ukuran Perusahaan bernilai 0.00314 , yang artinya ketika ukuran perusahaan meningkat satu satuan maka akan menambah kualitas audit sebesar 0.00314

4) Variabel Audit Tenure bernilai 17.83137, yang artinya ketika audit tenure meningkat satu satuan maka akan menambah kualitas audit sebesar 17.83137 .

\section{Koefisien Determinasi}

Dari hasil regresi tersebut, nilai $\mathrm{R}$ square sebesar 0,119602. Hal ini berarti 11,96\% perubahan yang terjadi pada variabel dependen Kualitas Audit disebabkan oleh perubahan variabel independen pada penelitian ini yaitu Audit Tenure, Ukuran Perusahaan, dan Ukuran KAP. Sedangkan 88,04\% variabel dependen dipengaruhi oleh variabel lain diluar model regresi ini.

\section{Uji Simultan (Uji F)}

Dari hasil pengujian, diperoleh nilai $\mathrm{F}$ sebesar 4.301906 dan nilai probabilitasnya 0.006842 yang berarti lebih rendah dari signifikansi yang telah ditetapkan yaitu 0,05 . Sehingga dapat disimpulkan bahwa variabel Audit Tenure, Ukuran Perusahaan, dan Ukuran KAP secara simultan berpengaruh signifikan pada kualitas audit.

\section{Uji Parsial (Uji t)}

Uji parsial digunakan untuk mengetahui bagaimana pengaruh masing-masing variabel independen terhadap variabel dependen. Berdasarkan nilai Tabel 3, menunjukkan bahwa:

1) Audit Tenure dan memiliki nilai probabilitas yang lebih kecil dari tingkat signifikansi $(0,0029<0,050)$ yang berarti variabel tersebut berpengaruh secara signifikan terhadap kualitas audit. Nilai koefisien variabel audit tenure adalah -10,02779, berarti pengaruhnya bersifat negatif. 
2) Ukuran Perusahaan memiliki nilai probabilitas yang lebih besar dari tingkat signifikansi $(0,8099>0,050)$ yang menunjukkan bahwa pengaruh yang diberikan oleh Ukuran Perusahaan tidak signifikan.

3) Ukuran KAP memiliki nilai probabilitas yang lebih kecil dari tingkat signifikansi $(0,0294<0,050)$ yang berarti variabel tersebut berpengaruh secara signifikan terhadap kualitas audit. Nilai koefisien variabel Ukuran KAP adalah 17,83137, berarti pengaruhnya bersifat positif..

\section{Pengaruh Audit Tenure Terhadap Kualitas Audit}

Variabel Audit Tenure memiliki koefisien -10,02779 yang berarti berpengaruh negatif terhadap kualitas audit. Hal ini sesuai dengan penelitian yang dilakukan oleh Pramaswaradana (2017) menyimpulkan bahwa audit tenure berpengaruh signifikan negatif terhadap kualitas audit.

Audit tenure memiliki pengaruh negatif bagi kualitas audit karena masa perikatan audit yang semakin lama mungkin menimbulkan potensi kedekatan antara auditor dan auditee yang dapat menimbulkan conflict of interest sehingga kualitas audit pada perusahaan yang jangka waktu perikatan audit nya lebih lama, cenderung lebih tidak akuntabel karena conflict of interest tersebut. Di Indonesia, audit tenure pernah diatur Peraturan Menteri Keuangan Republik Indonesia Nomor 17/PMK.01/2008 tentang Jasa Akuntan Publik.

Berdasarkan peraturan tersebut, pemberian jasa audit umum atas laporan keuangan dari suatu entitas dilakukan oleh KAP paling lama untuk 6 (enam) tahun buku berturut-turut, dan oleh seorang akuntan publik paling lama untuk 3 (tiga) tahun buku berturutturut. Akuntan publik dan kantor akuntan boleh menerima kembali penugasan audit umum untuk klien setelah satu tahun buku tidak memberikan jasa audit umum atas laporan keuangan klien tersebut. Kemudian, peraturan ini dicabut dengan diterbitkannya Peraturan Pemerintah Nomor 20 Tahun 2015 tentang Praktik Akuntan Publik.

\section{Pengaruh Ukuran Perusahaan Terhadap Kualitas Audit}

Variabel ukuran perusahaan tidak memiliki pengaruh signifikan pada kualitas audit berdasarkan hasil uji parsial yang dilakukan. Tidak berpengaruhnya ukuran perusahaan terhadap kualitas audit salah satunya disebabkan oleh adanya kesamaan dalam hal kapitalisasi saham perusahaanperusahaan dalam populasi. Mengingat LQ45 merupakan daftar 45 perusahaan dengan kapitalisasi terbesar yang terdaftar di Bursa Efek Indonesia, sehingga dapat dikatakan bahwa seluruh populasi merupakan perusahaan dengan kapitalisasi saham yang cukup besar dan tidak memiliki perbedaan signifikan dalam hal kapitalisasi saham nya. Hal tersebut mengakibatkan tidak adanya perbedaan yang signifikan antar perusahaan dalam hal ukuran perusahaan dan pengaruhnya pada kualitas audit.

\section{Pengaruh Ukuran KAP Terhadap Kualitas Audit}

Variabel ukuran Kantor Akuntan Publik (KAP) memiliki koefisien sebesar 17,83137 yang menunjukkan bahwa variabel ini berpengaruh positif terhadap kualitas audit. Hal ini sejalan dengan hasil penelitian yang dilakukan Febriyanti et. al. (2014) dan Cameran (2018) yang menyatakan bahwa ukuran KAP berpengaruh positif pada kualitas audit.

KAP yang terafiliasi dengan KAP Big 4 memiliki sumber daya yang mampu memenuhi seluruh standar audit yang ditetapkan sehingga dapat memegaruhi kualitas audit yang dihasilkan. Dengan menggunakan jasa audit dari KAP Besar, kualitas audit dalam aspek perceived quality atau kualitas yang dirasakan terkait dengan kepercayaan bahwa salah saji material dalam laporan keuangan telah diungkap lebih mudah diraih.

\section{KESIMPULAN}

Simpulan yang dapat ditarik dari penelitian ini adalah audit tenure memiliki pengaruh signifikan negatif terhadap kualitas audit, kemudian ukuran perusahaan tidak memiliki pengaruh signifikan terhadap kualitas audit, dan ukuran Kantor Akuntan Publik (KAP) memiliki pengaruh positif dan signifikan terhadap kualitas audit.

\section{REFERENSI}

Cameran, M., Campa, D., \& Francis, J.R., (2018). Audit Effects of Accounting Firm 
Organization Levels. SSRN Electronic Journal.

Chadegani, Arezoo Aghaei. 2011. Review of Studies on Audit Quality. International Conference on Humanities Society and Culture, Vol. 20. Singapore.

De Angelo, L. (1981). Auditor size and audit quality. Journal of Accounting and Economics Vol. 3 Issue 3, 183-199.

Febriyanti, N. M. D., \& Mertha, I. M (2014). Pengaruh Masa Perikatan Audit, Rotasi KAP, Ukuran Perusahaan Klien, dan Ukuran KAP pada Kualitas Audit. E-Jurnal Akuntansi Universitas Udayana.

Fernando, G. D., Ahmed M., dan Randal J. E. 2010. Audit quality attributes, client size and cost of equity capital. - Review of Accounting and Finance. 9(4): h: 363-381.

Hartadi, Bambang. (2012). Pengaruh Fee Audit, Rotasi KAP, dan Reputasi Auditor Terhadap Kualitas Audit di Bursa Efek Indonesia. Ekuitas Jurnal Ekonomi dan Keuangan

Institut Akuntan Publik Indonesia. 2013. Standar Profesional Akuntan Publik. Jakarta : Salemba Empat.

Jackson, A. B., M. Moldrich, dan P. Roebuck. 2008. Mandatory Audit Firm Rotation and Audit Quality. Managerial Auditing Journal 23(5): 420 - 437.

Jensen, M. C., dan W. H. Meckling. 1976. Theory of The Firm: Managerial Behavior, Agency Costs and Ownership Structure. Journal of Financial Economics 3(4); 305360

Maharani, Putri Adisti. (2014). Pengaruh Audit Tenure, Audit Fee, Rotasi Audit, dan Spesialisasi Auditor terhadap Kualitas Audit. Skripsi Fakultas Ekonomika dan Bisnis Universitas Muhammadiyah Surakarta.

Kurniasih, Margi. (2014). Pengaruh Fee Audit, Audit Tenure, dan Rotasi Audit, terhadap Kualitas Audit. Skripsi Fakultas Ekonomika dan Bisnis Universitas Diponegoro

Paramita, N. K. A., Latrini M. Y. L. (2015). Pengaruh Ukuran Perusahaan, Umur Publikasi, Masa Perikatan Audit, Pergantian Manajemen Pada Kualitas Audit. E-Jurnal Akuntansi Universitas Udayana.13(1), 142156.

Permana, Klaudia Xary. 2011. Pengaruh Masa Perikatan Audit dan Ukuran KAP terhadap Kualitas Audit. Universitas Diponegoro.
Pramaswaradana, I. G. I., \& Astika, I. B. P. (2017). Pengaruh Audit Tenure, Audit Fee, Rotasi Auditor, Spesialisasi Auditor, dan Umur Publikasi pada Kualitas Audit. EJurnal Akuntansi Universitas Udayana

Sinaga, Daud M.T (2012). Analisis Pengaruh Audit Tenure, Ukuran KAP dan Ukuran Perusahaan Klien terhadap Kualitas Audit. Skripsi Fakultas Ekonomika dan Bisnis Universitas Diponegoro

Watts, R. L., \& Zimmerman, J. L. (1986). Positive accounting theory.

Wibowo, A., \& Rossieta H. 2009. FaktorfaktorDeterminasi Kualitas Audit: Suatu Studi dengan Pendekatan Earnings Surprise Benchmark. Simposium Nasional Akuntansi XII

Widyaningsih, I. A., Harymawan I., Mardijuwono, A. W., Ayuningtyas, E. S., Larasati, D. A., (2019). Audit Firm Rotation and Audit Quality : Comparison before vs after the elimination of audit firm rotation regulations in Indoensia. Cogent Business and Management. 